\title{
SCIENTIFIC-METHODOLOGICAL AND PRACTICAL PRINCIPLES OF REGIONAL ECONOMIC SYSTEMS INTEGRATION
}

\author{
Anatolii Mazur', Oksana Kubai²
}

\begin{abstract}
The purpose of this study is to identify and describe the trans-boundary economic interactions and crossborder development of the regions in various organizational forms of cooperation as a direction of globalization of the regional economic systems. Study of transformational processes in the national economy from the perspective of regionalization of social development opens up a list of scientific problems that are already urgent today and in the future will require new or additional justification. First and foremost, they include justification of the content and essence of economic regions, which operate outside the common market of the state and which are open for other national systems of the world economy within the framework of the interregional cooperation. Practice shows that territorial and economic systems are not limited to political and administrative boundaries but are able to function beyond their borders. This tendency needs scientific and theoretical justification in the meaning of a new paradigm of regional development. Methodology. The methodological basis for the study of theoretical and practical aspects of the functioning and development of regional economic systems in the conditions of interregional cooperation is the modern theories and concepts of regional development, including transborder cooperation. Practical implications. Modern publications do not adequately and deeply consider the issues of the nature of emergence and organization of regional communities' international interactions, peculiarities of the forms of organization and economic feasibility of their existence. The essence of the research lies in justification of the scientific concept of development of the regions' cross-border interaction as the objective tendency synthesis of the state and regions in the implementation of the extended economic reproduction. The article deals with the theoretical and practical issues of the regional economic communities' development in the trans-boundary space of Ukraine. The terminological concepts "national economy" and "economy of Ukraine" are distinguished. And the necessity of promoting for Euroregions creation, expansion of cross-border cooperation was established. Value/ originality. It is established that the modern development of the world economy is based on the interaction of the border regions, which in total provide the cross-border movement of goods and services in the globalized economy.
\end{abstract}

Key words: integration, regions, processes, systems, development, regionalization, globalization.

JEL Classification: R58, B41, P43

\section{Introduction}

The problem of reducing the "capacity" of the national governments in solving the economic problems in the conditions of globalization and regionalization of social development remains urgent during the last twentyyears. There are objective reasons for this. First, the autonomy of the entities that develop the economic policies at the level of the national economic complex is narrowing. Secondly, the circle of the economic and political market players, which influence the government decisions, is expanding. Thirdly, there is a new subject of economic interests - the international regional association. The process of regionalization initiated the emergence of

\footnotetext{
Corresponding author:

${ }^{1}$ Vinnytsia National Agrarian University, Ukraine.

E-mail: agment@vsau.vin.ua

ORCID: https://orcid.org/0000-0001-6385-3877

${ }^{2}$ Vinnytsia National Agrarian University, Ukraine.

E-mail: oksanakubai11@gmail.com

ORCID: https://orcid.org/0000-0001-5099-489X
}

two trends that affect the mechanism of the public administration: 1) activation of the foreign economic activity of the internal regions of the country and their desire to gain greater independence in making strategic decisions; 2) dependence of transnational cooperation of the country on the achieved arrangements and agreements within the framework of the international regional associations. All these points put the science before the difficult task of theoretical rethinking of the role and importance of the state in regulating the social relations and design of regionalism as a science and practice of the economic transformation both within the state and abroad. 
Transformation processes in the national economy inevitably lead to the transformation of the state governance mechanisms, which manifests itself in the growing importance of the interregional market for goods and services, which leads to the weakening of the state's position, the existing mechanisms in the field of the economic policy also substantially change. If in the 50s and the 60s the main influence on the decision making was made by the factors of the national level, at present the world economic system should be considered as a complex three-level combination of the national, regional, and international markets as such, whose subjects interacting with each other, determine the effective vector of the economic policy of national states and supranational economic institutions.

The design of the updated regionalism for the business practice forms the vector of regionalism as a new paradigm of the social development, in which the regional economies act as a "generator" of the economic reproduction. Changing the paradigm offers a variety of new research challenges, which it can deliver, as well as the usefulness of the practical measures it can encourage. The aforementioned aspects only reveal a list of problems that in the future will require new or additional research.

The urgency of the identified topics and the lack of the generally accepted vision of the interregional ties and intergovernmental economic development on their basis dictates the need for a deeper consideration of the essence of the regions integration as the economic category of describing the peculiarities of their formation and defining the prospects for the growth of the national economies through the contribution of regional economic systems.

\section{Fragmentation of the common market of the regions of Ukraine}

The reality of the present is that the central government structures and their governing bodies in the regions and at the local level believe that they have the power for the subordinate and politically defined economy, although in practice they are not able to determine the real economic area of influence. As a result, certain territorial units subordinate to other management structures and regions, and within the boundaries of the country - to other states.

The state controls the entire economy and regions, the state administrations - the administrative areas subordinated to them, as if they are the economic structures, and the local governments develop economic growth strategies in the subordinate territories, considering that their sphere of influence extends within the specified boundaries. These durability and vitality of the central trend of management are clear - it serves as a platform for defining and implementing the course of the state economic policy.

The government must objectively see the whole economy, the local governments also believe in their holistic vision of the economic reality, and the regions consider the economy as an existing state system. To a large extent, such a perception of the economic realities is a distortion of the economic reality and simplification of the real political economy. The situation is radically changing when considering the national economy from the perspective of the regional paradigm of development (Figure 1).

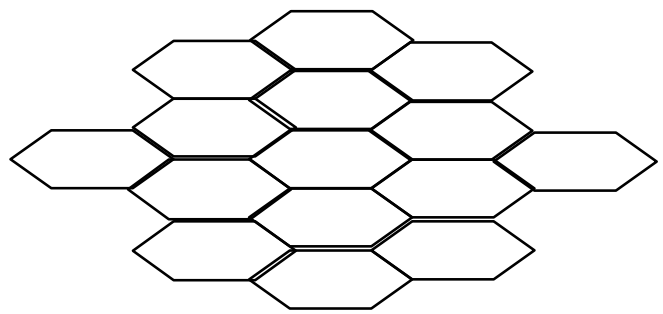

Figure 1. System of the Economic Regions

In this case, the aggregate of the economic regions (Fig. 1) forms the national economy. However, if the national economy lies within the borders of the state's national boundaries, the boundaries of the economic regional communities are defined by the sphere of influence of these economies on the economic space. It is clear that this discrepancy is not in favour of the

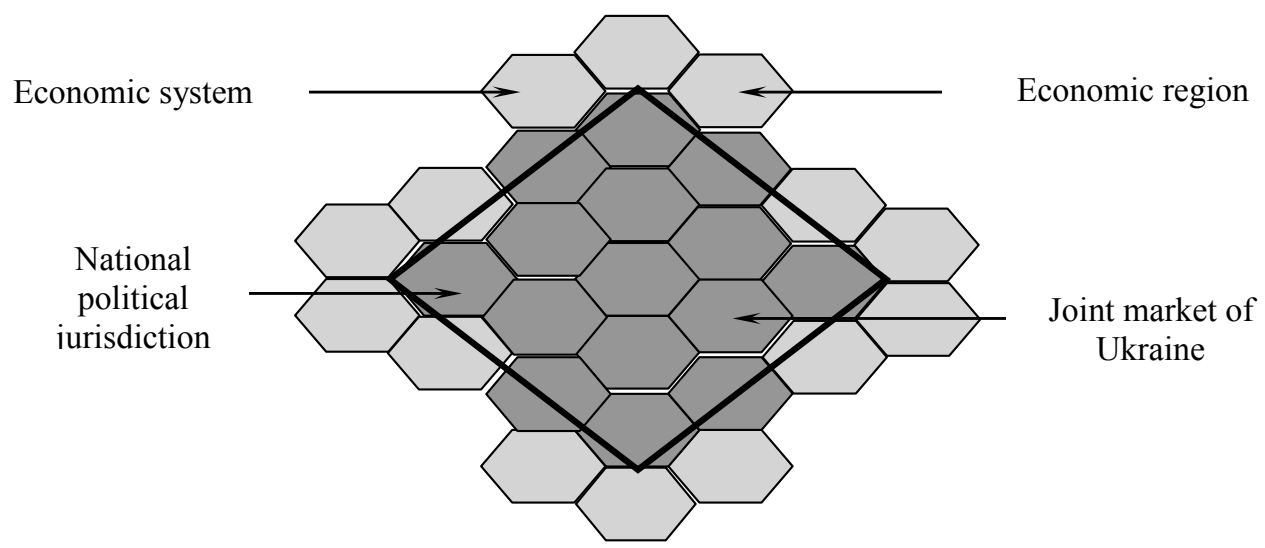

Figure 2. The Common Market of Ukraine 
national government since it loses its influence on economic activity, which is beyond its jurisdiction. The situation becomes clear when the aim is to define the territory of influence of the central governmental bodies. Obviously, this will be a common market (Figure 2).

So, as can be seen from Fig. 2, the geographical boundaries of the common market serve as the jurisdiction of the national government, but this is not the entire national economy. Part of the economic space goes beyond the common market and does not subordinate to the national government, being within the national boundaries of the country. In practice, these territories are the objects of the various forms of cross-border cooperation. This reality brings us to the specification of economic terminology. Obviously, the term "national economy", in our understanding, means the boundaries of the economic regions within the jurisdictions of the national government and, accordingly, the common market. The "Economy of Ukraine" is a broader term in the content; it denotes the entire national economic system, including that part that extends beyond the national boundaries (Mazur, 2007).

\section{Enhancement of regional influence on economic development}

The last decade of the twentieth century and the beginning of the twenty-first century fully testify to the fact that the global economic processes are becoming increasingly dominant, pushing the national economies in the background and as if dissolving them in a giant economic mechanism. During this transformation, one of the most important turning points in the history of the world society occurs, yet not enough understood by the theoretical science and practice - the devaluation of the states, which for many decades have been the systemforming organizational structures. The boundaries of the national states have become tight for the productive forces, which have begun to evolve at a rapid pace, and as a result, the generated market structures have gone well beyond the national boundaries and economies.

The national states have faced a fundamentally new situation: they lose the opportunity to effectively use such levers of the traditional macroeconomic regulation as import barriers and export subsidies, the national currency rate, and the refinancing rate of the central national bank. With the expansion of globalization processes, the increasing part of the state sovereignty is distributed between the regional and global regulatory institutions (Kuhn, 1970). At the same time, in the governmental structures, the international trade is interpreted on the basis of the national understanding, defining the state borders of Ukraine as the border between "our" and "their" economies.

Beginning of the radical economic reforms in the state has become even more accompanied by a shift in emphasis from the trade with the CIS countries to the ties with other countries of the world. In the developed countries of the world, about one-fifth of the domestic products produced within the country are sold on the external market. Thus, the export quota of GDP of the large European countries ranges within 21-24\%, and only in the small Western European countries, it makes up about 40\% (Horovyi, 2002).

\section{Directions of the development of regional economic systems}

The mentioned information emphasizes a new direction in the development of the regional economic systems, which needs theoretical understanding.

Recently, more and more researches are concentrated on the components of the economic activity at the border of the administrative boundaries of Ukraine and other foreign countries. This makes us take a new look at the modern economy in general and at Ukrainian one, in particular. Of course, the deep meaning is often lost in the scientific discussions, where each scientist defends his ideas, but such activities substantially enrich the original hypotheses. The opposite approach characterizes the economic world as a set of the independent productions and workers who solve their production and sales, as well as personal problems in chaotic conditions of the political economy (Barnes, Ledebur, 2003).

The thesis and antithesis, in this case, should not be interpreted as politics and economics that cannot be understood, but on the contrary - as an opportunity of politics and economics to create a new vision of the political economy. In other words, it is necessary to find a consensus between politics and economy, in order to successfully and on a scientific basis solve urgent problems of the present both from the part of the national governments and subjects of the regional economic relations. Hence the basis of the positive promotion of reality on the part of both participants is proposed: the national economy is a set of the regional economies, that's why the boundaries of the government influence on their activities are determined only by the common market; the nonmatching of the administrative boundaries of the country with the economic space, which subordinate to specific regions, creates preconditions for the interpenetration of the economic relations beyond the borders between the neighbouring states (Figure 3) (Mazur, 2007).

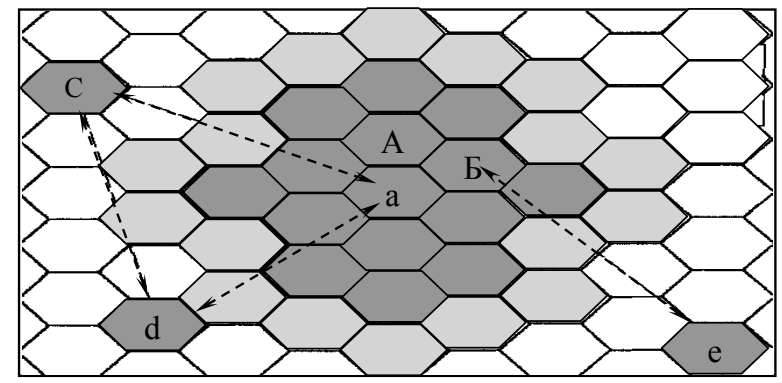

Figure 3. Global Economic Interdependence 
For example, $\mathrm{A}$ is a system of the regional economies of Ukraine, and B - surrounding economic regions of the neighbouring countries. In this case, most of the economic regions of Ukraine (system A) border and have common boundaries with the economic regions of other economic systems (Russia, Moldova, Romania, Poland, and Hungary).

In reality, the intensity of interdependence of the regions can become more complex. Fig. 3 gives the opportunity to see the dependence under the influence of the market of two economic regions of different economic systems (for example, the Baltic States - c, Switzerland - d, Vinnytsia region - a, of the economic system A of Ukraine) in implementation of the integration economic processes.

\section{The essence and content of interregional integration}

We emphasize that the category "economic integration" should have at least two meanings. The first one is based on an understanding of the interdependence of the industrial sectors in the economy and the vertical and horizontal integration of industries. The second one we interpret as an association of the economic activity, especially the trade of several countries, for example, through creating free trade zones, customs unions, common markets, and economic unions (Storonianska, 2004).

In accordance with the second meaning, we observe the integration of the regional economies and economic systems when one or more economic regions become an integral part of two different economic systems, with certain local economies becoming parts of each of them managed jointly. For example, the Transcarpathian region as a region is the part of two economic systems - Ukraine and Hungary; Lviv region of three ones - Krakow voivodeship (Poland), Tiumen region (Russia), Transdnistria (Moldavia), etc. Logics of the integration processes become clear when imposing the state boundaries on the global network of economic systems and their economic regions (Figure 4).

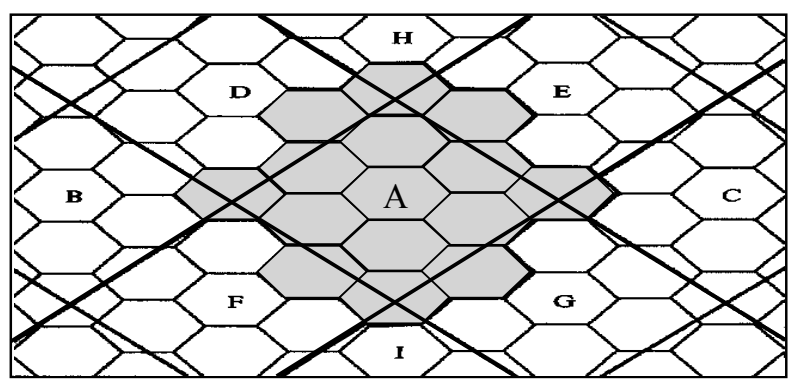

Figure 4. Global Economy (rhombi A-G - regional economies)

The data of Figure 4 allow making at least two intermediate judgments: 1) the economic systems go beyond the national political jurisdiction; 2) they are subject to the jurisdiction of other countries. Accordingly, for those regions beyond the national boundaries and under the integration, the growth will depend on the successful functioning of these economic systems and decisions of the external and internal order of these states.

\section{Forms of interregional cooperation}

The regional activity of the countries is manifested in their participation in the international agreements (WTO Secretariat Regional Trade Integration under Transformation (2002). The seminar is Regionalism and the WTO, Geneva). Moreover, the latest trend identified by WTO is increase in the number of countries that choose the trade integration agreements as a prerequisite for implementing an expanded scheme of deeper integration within the region. Formation of the regional unions is considered as:

a) the method of the rapid transformation of the economic complexes on the basis of the advantages of international cooperation;

b) the form of the regional association to confront the stronger entities of the world economy and minimize the negative effects of globalization;

c) the possibility of integration within the region for the formation of the additional competitive advantages, as well as common mechanisms for agreement and harmonization of interests of the countries (Petrenko, 2003).

The presented theoretical aspects of the essence and reasons for the economic integration of the regions are confirmed in practice. In the boundary belt of Ukraine in 1993, the international Association "Carpathian Region" was created which included 5 regions of Hungary, 3 neighbouring voivodeships of Poland, 6 regions of Slovakia and Transcarpathian, Lviv, Ivano-Frankivsk, and Chernivtsi regions of Ukraine. The purpose for the creation of this association is to organize and coordinate the joint activities, promote the economic, scientific, environmental, cultural, sporting, educational cooperation, as well as support for individual projects for development of the border infrastructure of the neighbouring territories, promote the contacts and cooperation of the international organizations (Petrenko, 2003).

In September 1995, the agreement on the creation of Euroregion Bug between Biała Podlaska, Chełm, and Lublin voivodeships of Poland, Volyn region of Ukraine, and Brest region of Belarus was signed. Later, Lviv region joined the agreement. The main task of the Euroregion Bug activity is: design of the strategy for development of the Euroregion; creation of the information base; organization of the advertising campaign of the Euroregion and attraction of the foreign investments; 
development of the communication infrastructure projects; development and implementation of the environmental projects, including "Clean Bug"; organization of joint trade, cultural and sports events (Bielienkii, 1996).

The priority for the creation of Euroregions at the western borders of Ukraine does not exclude the possibility of creating them on the borders with Russia, which has many positive points - both for Ukraine and for Russia.

In 2003, the Euroregion Dnipro (Chernihiv region of Ukraine, Briansk region of the Russian Federation, Gomel region of the Republic of Belarus) was created on the eastern border of Ukraine. At present, the corresponding work on the formation of the Euroregions Yaroslavna (Sumy region of Ukraine and Kursk region of the Russian Federation), Dniester (Vinnytsia, Odesa regions of Ukraine and border counties of the Republic of Moldova) is carried out. The prospect of creating the Euroregions Slobozhanshchyna is quite realistic, which on the basis of Kharkiv and Belgorod regions can later include other neighbouring regions - Sumy, Poltava, and Luhansk on the part of Ukraine and Kursk and Voronezh - on the part of Russia. The issue of developing the project of Euroregions Sian (Lviv region of Ukraine and Podkarpackie voivodeship of the Republic of Poland) is under consideration. There are negotiations on the entry of the Mykolaiv region of Ukraine into the Euroregion Pomerania (Mikula, 2003).

In 2005, a new step in Ukraine-EU relationship within the framework of the "Wider Europe" initiative was taken, which was supported by the last stage of EU extension. The European Neighbourhood Policy proposed the instruments, which should provide the new impulse to cross-border cooperation: moreover, in the long run, this instrument can be extended to all regions of Ukraine, which will stimulate the interregional cooperation as a whole, and the "Neighbourhood Programs" themselves have the potential to become such an instrument. Today, Ukraine is offered four such programs: "Poland - Ukraine - Belarus" (with the indicative TACIS funding budget of $€ 8$ million for the whole period), Hungary - Slovakia - Ukraine (with the indicative TACIS funding budget of $€ 4$ million for the whole period), Romania-Ukraine (with the indicative TACIS funding budget of $€ 6,5$ million for the whole period), and the transnational program (CADSES initiative (with the indicative TACIS funding budget of $€ 5$ million for the whole period for Ukraine and Moldova)) (Voloshko, 2005).

In 2012, on the initiative of Vinnytsia region, the transnational formation of the Euroregion Dniester was founded.

It comprised of Vinnytsia region and six administrative districts of the Republic of Moldova. The aim of the association is the implementation of the integrated and harmonious development of the territories adjacent to river Dniester. Realization of this goal involves the following:

1) organization, coordination, and deepening of relations in the economy, trade, science, education, culture, tourism;

2) implementation of the common cross-border investment projects;

3) implementation of the regional projects on the reduction of unemployment among the population of the border regions by increasing the economic potential; 4) organization of contacts with the relevant international organizations, foundations, institutes, agencies, and other organizations.

The main promising projects include:

1. The bridge across the river Dniester in Yampil, Vinnytsia region (the estimated cost is $€ 9$ million).

2. Construction of sewage treatment in settlements of Vinnytsia region and Moldova along the river Dniester (the estimated cost of works is $€ 5$ million.

3. Construction of the international Vinnytsia) airport.

4. Construction of roads to Bronnytsia-Ungur crossing point (the estimated cost is $€ 3$ million).

The experience of the functioning of Euroregions is currently considered to be the most efficient organization of cross-border cooperation. Under conditions of overcoming the problematic moments in organization and activity of the existing Euroregions and in attracting other border areas of Ukraine to the process of integration in the form of Euroregions, the most effective use of the potential of the border areas of the country is possible, which, firstly, will provide the greater independence in the development of these regions, and secondly, will fully stimulate the process of integration of the country into the world values by joining the European Economic Space.

There are examples of less fortunate and formalized participation of border countries in the form of combinations of transnational alliances, such as the Berentz-European Council, Council of the Baltic States, etc. (Euro (1999) "Severnoe Syianye" v polytyke Evropeiskoho Soiuza ["Northern Light" in the policy of the European Union], Moscow: Euro). They are experimental in the sense that the composition of their participants testifies to the desire to establish horizontal cooperation between NATO member states, neutral states, and post-Soviet republics.

\section{Reserves of interregional cooperation}

The analysis of the cross-border cooperation with the participation of Ukrainian regions gives grounds for talking about the existence of a number of obstacles and problems of development, which should include the following: 
1. Lack of effective regional policy of cross-border cooperation, which is associated primarily with the crisis social and economic situation of Ukraine as a whole.

2. Existence of the significant differences in administrative and territorial arrangements and patterns of territories division in accordance with EU standards. This can include the differences in the current legislation in relation to the "field of the economic activity" (customs, tax, banking, and insurance regulation).

3. Differences in the development of the adjacent border regions, in particular, limitation of the financial security, which restrains participation of the local authorities in the international development projects.

4. Limitation of powers and rights in accordance with the current legislation of the local self-government bodies regarding participation in the international associations, establishment of the foreign economic relations, etc.

5. Low awareness of the feasibility and possible results of Euroregional associations' activity with participation of the border regions of Ukraine and lack of a clear position on the legitimacy of this activity.

At the same time, the perspective of this direction of economic development is obvious. The border area of Ukraine covers 96 administrative districts and 5 areas of city councils; 19 out of 25 regions of the state are border ones. The natural and resource potential of these territories makes up $18.5 \%$ of the potential of Ukraine, and the population $-21.8 \%$. The industry of the border territories employs $22.8 \%$ of the production and industrial potential of the country; and almost $19 \%$ of the industrial products of Ukraine are manufactured (Pila, Chmir, 2003).

The concrete proposals on the main directions of Ukraine's adaptation to the world market should come from the already adopted course on multi-vector, development of relations with CIS countries, and especially with Russia, and with the need to expand the economic ties with EU countries.

Since it is difficult to build one's own economy and relations with other countries alone, participation in the regional organizations is a perspective for Ukraine. UNO, as already noted, recognizes the importance of the regional groupings to accelerate the process of globalization and facilitate the participation of national governments in them (Klochko, 2001).

\section{Directions for improving the regulatory influence on the nature of interregional integration processes}

Inclusion of Ukraine in the globalization processes mostly depends on the formation of a new mechanism of the foreign economic activity, based on the principles of ensuring the continuous nature of the economic ties, a gradual transition from the administrative to self-regulating system, demonopolization, deideologization, compliance with the criteria of the economic cooperation, guaranteeing the country's security. In our opinion, formation of the basics of such mechanism (legal bases, organizational forms, economic upsurges) will go towards unification with the world structures, creation of the real incentives for foreign investors, consistent implementation of the economic reform in this field, reduction of the exaggerated dependence of Ukraine on the external revenues, products of fuel and energy complex, grounded protectionism, promotion of new equipment and technologies attraction.

\section{Conclusions}

Conducted researches of the theory and practice of the integration processes of the regional economies allow making some important generalizations:

- the global economy is a system of interconnected economic systems and their components - regional economies;

- government structures and economies do not coincide in the global economy; therefore, nations are economically interdependent and have common elements of the economic systems within the common markets;

- the states, which possess the parts of the economic system, located within their national boundaries, are interested in the effective operation of the whole economic system, which is proved by the practical examples of cooperation;

- the policy directed only to the economy within the borders of the national boundaries to ensure the growth of the competitive advantage of one of the countries will necessarily have a retroactive effect on the activity of each of the economic systems.

The trends in the world economic development in the most concrete form affect the specifics of the border areas management, namely:

- such regions legally ensure the cross-border movement of goods in the conditions of trade liberalization;

- the border regions carry out contact and barrier functions under the pressure of the dynamic growing trans-border movement of the population in the form of the international migration of labour resources, tourism, business and educational trips, which is a manifestation of globalization of the world intereconomic relations;

- the regional integration associations are formed in the event of backward or repressiveness of the border areas due to their peripheral positions;

- the general educational trend includes strengthening the rights and empowering the local authorities, in particular, in the area of cooperation with the relevant authorities of the neighbouring territories of foreign countries. 


\section{References:}

Kuhn, T. S. (1970). The structure of scientific revolution - 1970. Chicago: University of Chicago Press. Retrieved from: https://projektintegracija.pravo.hr/_download/repository/Kuhn_Structure_of_Scientific_Revolutions.pdf Horovyi, V. P. (2002). Stanovlennia zovnishnoekonomichnykh zviazkiv u period hlobalizatsii ekonomiky [The formation of foreign economic relations in the period of globalization of the economy]. Journal of Economy of agroindustrial complex, 5, 20-26. (in Ukrainian)

Barnes, V., Ledebur, L. (2003). Novi rehionalni ekonomiky [New regional economies], Lviv: Chronicles. (in Ukrainian)

Storonianska, I. (2004). Chynnyky dezintehratsii rehioniv Ukrainy ta shliakhy formuvannia modeli vnutrishnoderzhavnoi mizhrehionalnoi intehratsii [Factors of disintegration of regions of Ukraine and ways of forming a model of interstate interregional integration]. Journal of Regional economy, 2, 79-86. (in Ukrainian)

WTO Secretariat Regional Trade Integration under Transformation. The seminar is Regionalism and the WTO. (2002). Geneva 26, April. Retrieved from: http://www.wto.org/english/tratop_e/region_e/sem_april02_e/ sem_april02_e.htm/

Petrenko, Z. (2003). Prykordonni rehiony yak nova forma mizhnarodnoi intehratsii [Border Regions as a New Form of International Integration]. Journal of Economy of agroindustrial complex, 12, 18-26. (in Ukrainian)

Bielienkii, P. Iu. (1996). Transkordonne spivrobitnytstvo: problemy i perspektyvy [Trans-border cooperation: problems and perspectives]. Lviv: Yuryst. (in Ukrainian)

Mikula, N. (2003). Yevrorehiony: dosvid ta perspektyvy [Euroregions: experience and perspectives]. Lviv: National Academy of Sciences of Ukraine. (in Ukrainian)

Voloshko, V. (2005). Realii ta perspektyvy transkordonnoho spivrobitnytstva [Realities and Prospects of Cross-Border Cooperation of Ukraine ], Journal of Regional economy, 4, 10-17. (in Ukrainian)

"Severnoe Syianye" v polytyke Evropeiskoho Soiuza ["Northern Light" in the policy of the European Union]. (1999). Moscow: Euro, 1, 21-28. (in Russian)

Pila, V. I., Chmir, O. S. (2003). Mekhanizm upravlinnia mizhterytorialnym i prykordonnym spivrobitnytstvom [Mechanism of management of interterritorial and border cooperation]. Journal of Scientific herald of Chernivtsi University, 4, 31-38. (in Ukrainian)

Klochko, V. (2001). Hlobalizatsiia ta yii vplyv na krainy z perekhidnoiu ekonomikoiu [Globalization and its impact on transition economies]. Journal of Ukraine economy, 10, 18-24. (in Ukrainian)

Mazur, A. (2007). Rehionalna paradyhma suspilnoho rozvytku [Regional paradigm of social development]. Vinnytsia: Knyha-Veha. (in Ukrainian) 